RU Социолингвистическая мобильность и вариативность новозеландского тюремного жаргона

\author{
Трифанова С. С.
}

\begin{abstract}
Аннотация. Цель исследования - выявить социолингвистические свойства лексической номинации новозеландского тюремного жаргона - мобильность и вариативность его элементов в ареальном, локально-территориальном, профессионально-корпоративном и гендерном аспектах. Научная новизна работы состоит в том, что впервые в контексте субстандартной лексикографии проводится анализ отмеченных социолингвистических особенностей лексем этой малоизученной в отечественной англистике речевой микросистемы. Полученные в ходе социолексикографического описания результаты показали, что социолингвистическая мобильность элементов новозеландского пенитенциарного социолекта проявляется в их перемещении в пределах культурно-языковых ареалов, исправительных учреждений Новой Зеландии, корпоративных и профессиональных групп макросистемы полинационального английского языка в целом; социолингвистическая дифференциация обусловлена локализацией употребления единиц, гендерной принадлежностью коммуникантов и их ролевой функцией в сообществе заключенных. В статье уточняются основные понятия, связанные с темой исследования.
\end{abstract}

\title{
EN Sociolinguistic Mobility and Variability of New Zealand Prison Argot
}

\author{
Trifanova S. S.
}

\begin{abstract}
The research aims to identify the sociolinguistic properties of lexical naming in New Zealand prison argot, namely mobility and variability of its elements in the areal, local-territorial, professional-corporate and gender aspects. The work is novel in that it is the first to analyse the noted sociolinguistic features of lexemes of this speech microsystem, which has been little studied in Russian Anglistics, in the context of substandard lexicography. The results obtained during the sociolexicographic description showed that sociolinguistic mobility peculiar to the elements of New Zealand penitentiary sociolect is manifested in their movement within cultural and linguistic areas, New Zealand correctional institutions, corporate and professional groups of the macrosystem of the multinational English language as a whole; sociolinguistic differentiation is accounted for by localisation in the use of units, communicants' gender identity and their role function in the inmate community. The paper clarifies the basic concepts related to the research topic.
\end{abstract}

\section{Введение}

Актуальность темы обусловлена повышенным интересом к углубленному изучению социальных вариантов языка, одним из которых является новозеландский тюремный жаргон, социолингвистическими особенностями, формой и семантикой отражающий характерное для тюремного сообщества Новой Зеландии представление об окружающей действительности.

Поставленная цель требует решения следующих задач: 1) выявить социолингвистическую ареальную, локально-территориальную и профессионально-корпоративную мобильность тюремных жаргонизмов внутри и за пределами рассматриваемой социально-речевой микросистемы; 2) раскрыть социолингвистическую вариативность лексем социолекта в зависимости от исправительного учреждения, в котором они употребляются, гендерных особенностей представителей новозеландской тюремной субкультуры и выполняемой ими общественно-трудовой деятельности.

В качестве основного метода исследования использовался социолексикографический анализ словарных статей.

Теоретической базой исследования послужили труды В. П. Коровушкина и Г. В. Рябичкиной в области субстандартной лексикологии и лексикографии [2-5]. Исследование проводилось на материале словаря новозеландского тюремного жаргона под редакцией Д. Лузер [9], насчитывающего 3000 словарных статей. Словарь 
является единственным на сегодняшний день социолексикографическим источником новозеландских пенитенциарных социолектизмов.

Практическая значимость работы состоит в том, что материалы и выводы исследования могут быть использованы при разработке спецкурсов по лексикологии и лексикографии, а также для написания выпускных квалификационных работ.

\section{Основная часть}

Новозеландский тюремный жаргон - это специфическая социально обусловленная форма существования новозеландского национального варианта английского языка (NZE) в виде совокупности корпоративномаркированных лексем с различной степенью этико-стилистической сниженности и экспрессивности, которая соответствует социолингвистической норме второго уровня, называет специальные и обычные явления окружающего мира, создает ситуацию неполной лексической диглоссии, обслуживает преимущественно эмотивно-коммуникативные потребности членов тюремного социума Новой Зеландии и способствует языковому обособлению последних и их противопоставлению обществу в целом [7, с. 64].

Своими истоками тюремный жаргон NZE восходит к средневековому британскому кэнту - средству общения преступных элементов, и наряду с идентичными англоязычными социолектными формами британского, австралийского и американского лингвистических ареалов функционирует [8, p. 4] в рамках макросистемы полинационального английского языка.

Фиксируемые в просторечных словарях субстандартные лексиконы вкупе с языковыми особенностями составляющих элементов служат объектно-предметной областью исследования социолексикографии (понятия «субстандартный» и «просторечный» используются в работе как синонимичные). Социолингвистика же в данном случае выступает теоретическим фундаментом для анализа вариативности языка как результата отражения социальной дифференциации общества посредством социолексикографического инструментария [5, с. 5].

Социолингвистические свойства лексической номинации пенитенциарного социолекта NZE - вариативность и мобильность единиц достаточно детально можно установить в ходе социолексикографического анализа словарной статьи и ее структурообразующих компонентов обязательного и факультативного характера (вокабулы, дефиниции и помет разных типов (грамматических, стилистических, дериватологических, социолингвистических), авторских цитаций, паспортизированных иллюстративных примеров, этимологических данных соответственно), ср.: 1) вокабула: сносоLATE FROG; 2) грамматическая справка: $n$. - имя существительное; 3) дефиниция: 'an informer, a nark' 'осведомитель' (определение ЛЕ помимо литературных синонимов также может быть представлено посредством подробного толкования, информации справочно-энциклопедической направленности; здесь и далее по тексту перевод выполнен автором исследования; примеры и перевод словарных статей могут сокращаться без искажения смысла. - С. Т.); 4) функционально-стилистическая принадлежность: '...rhyming slang for dog of the same meaning...'; 5) социолингвистические признаки: а) ареальная мобильность в сочетании с темпоральной отнесенностью: (данная ЛЕ также функционирует в австралийском лингвистическом ареале): '...Australian from 1971.'; 6) авторская цитация, выполненная в целях семантизации словосочетания, содержащая социокультурные и этимолого-дериватологические сведения: 1973 McNEIL: 'In prison jargon, a "chocolate frog" denotes a dog. And a dog is one who violates or has violated in times past the informal "laws" of the prison society... And a dog should be judged, has to be punished, deserves to be ostracised and deprived as criminals are’ [9, p. 42]. / ‘В тюремном жаргоне словосочетание chocolate frog означает «собака». «Собака»тот, кто нарушает или нарушил в прошлом неформальные законы тюремного сообщества... «Собака» должна быть осуждена, наказана, заслуживает изгнания из общества и лишения свободы, как и все преступники'.

Рассмотрим далее социолингвистическую мобильность и вариативность тюремного жаргона NZE в соответствии с указанными задачами.

Тюремный жаргон NZE - динамичная неконвенциональная лексико-фразеологическая подсистема, которая, несмотря на относительную закрытость, отличается выраженной проницаемостью и подвижностью элементов в ареальном, локально-территориальном и профессионально-корпоративном аспектах, в результате чего происходит пополнение тюремного лексикона. Рассмотрим каждый вид мобильности более подробно.

Под ареальной мобильностью в работе подразумевается передвижение ЛЕ в границах культурно-языковых ареалов (данный процесс затрагивает стандартный и субстандартный уровни взаимодействующих языков). Среди наиболее значимых социальных предпосылок, оказавших влияние на перемещение лексем в NZE и его просторечные формы из других лингвистических ареалов, отмечаются существенный приток населения в Новую Зеландию в результате британской колониальной политики, а также языковые контакты маори и пакеха (новозеландских европейцев). К другим важным факторам, причастным к формированию тюремного жаргона NZE, относятся развитие средств массовой информации и коммуникации, географическая близость и усиление экономической интеграции Австралии и Новой Зеландии, общая история становления и развития пенитенциарных отношений двух стран.

В историко-лингвистическом отношении исследуемый жаргон представляет собой гибридную (как и NZE) социально-речевую микросистему, возникшую в результате совместного влияния британского (преимущественно), австралийского, американского национальных вариантов английского языка (BrE, AusE, AmE), а также языков полинезийской группы (маори, самоа) на NZE; данный вид мобильности в словаре Д. Лузер отражается 
в соответствующих ареальных маркёрах. Приведем здесь примеры передвижения лексем в тюремный жаргон новозеландского лингвистического ареала: из BrE: WEASEL British from early 1930s = an informer; NZ 1968 'доносчик', 'лицемер'; из AusE: SNOOKER prob. from Australian 'snooker' = to stymie, bewilder (1967) 'скрываться'; из AmE: тЕA ваG From US slang 'tea' = marijuana 'марихуана'; из маори: кUPENGA a transferred or figurative use of Maori kupenga = 'fishnet' ‘изолятор', ‘карцер'; из самоа: o fefe Samoan = 'no fear’ ‘все равно’ [Ibidem, p. 102, 125, 171-172, 185, 201].

Поскольку NZE образован преимущественно дериватами британского происхождения, лексемы в новозеландских толковых монолингвальных словарях не всегда сопровождаются ареальными указателями, ср.: вUS RIDE $n$. ‘перевод в другую тюрьму’ [Ibidem, p. 34].

Образования с рифмой в лексико-фразеологическом составе NZE как ареальная разновидность кокни бесспорное подтверждение влияния BrE на NZE и его тюремный жаргон и характерная черта последнего благодаря возможности таких ЛЕ функционировать в качестве секретного кода и средства вербальной конкуренции в словесных дуэлях. Данное явление предполагает субституцию искомых лексем вторичными наименованиями (композитами из трех-четырех слогов, словосочетаниями, выражениями), перенимающими смысловое содержание первых [1, с. 120; 8, p. 32-33].

Образования с рифмой существуют в двух вариантах [3, с. 348-349]: 1) рифмованные, как правило, именуемые собственно рифмованным сленгом, в которых материально представленный репрезентатор рифмуется с предполагаемым идентификатором (в скобках): OLD NED (head) 'голова' [9, р. 129], и 2) рифмующиеся, где компоненты в структуре деривата рифмуются между собой: SHARK IN THE PARK (nark) ‘доносчик’ [Ibidem, p. 163]. Подобные комбинации в своем буквальном значении отличаются искаженным смысловым наполнением, намеренно вводят адресата в заблуждение.

Так, для тюремного жаргона NZE характерны две разновидности образований с рифмой [8, p. 33-34]: 1) лексемы-криминализованные аналоги уже существующих тюремных социолектизмов, интерпретация которых требует знания лексикона конкретной преступной субкультуры; в силу подвижности границ полинационального английского языка подобные структуры проникают в тюремный жаргон NZE в результате межареальных переходов из лексиконов, в том числе профессионально-корпоративных, не только британского лингвистического ареала с последующим изменением семантики, ср.: ON THE MURRAY COD under the influence of intravenous drugs. [rhyming slang for on the nod, an underworld adaptation of Australian usages: ...on the Murray $\operatorname{cod}=$ on the nod (i.e. on credit, 1977)] ('под воздействием внутривенных наркотиков’ (первоначальное значение ‘в долг')) [8, p. 33; 9, p. 120]; (2) рифмованные корреляты специфичных для Новой Зеландии в культурном отношении лексем: ВАвE RUTH truth [rhyming slang; after the famous US baseball player (1895-1948)] ('правда' (в честь известного американского баскетболиста)) [9, р. 10]; здесь рифмованная субституция предполагает отнесенность к объектам и явлениям новозеландской культуры при отсутствии семантической связи с референтом.

Наиболее часто образования с рифмой в тюремном жаргоне NZE используются заключенными европейского происхождения в возрасте старше 30 лет (при этом частота употребления прямо пропорциональна возрасту). Молодые заключенные-уроженцы тихоокеанских островов и маори в силу этнической самоидентификации с афроамериканской субкультурой чаще употребляют афроамериканские социолектизмы, отождествляемые во многом с элементами уличного жаргона [8, р. 34].

Профессионально-корпоративная мобильность состоит в перемещении ЛЕ из одного социолекта в другой. В исследуемом материале условно можно выделить два вида мобильности: 1) в пределах специального лексического субстандарта NZE; 2) в пределах полинационального английского языка.

Отметим, что лексический субстандарт NZE - это сложная иерархически организованная форма существования NZE, объединяющая две речевые микросистемы - общенародный лексический субстандарт, включающий низкие коллоквиализмы, общие сленгизмы, вульгаризмы, и специальный лексический субстандарт, содержащий элементы профессионально-корпоративных жаргонов, маргинальных субкультур и кэнтизмы [6, с. 6]. Новозеландский тюремный социолект является неотъемлемым компонентом специального лексического субстандарта NZE. Так, в словаре Д. Лузер представлены тюремные жаргонизмы, которые также функционируют / функционировали в следующих лексиконах (чаще) девиантных и маргинальных субкультур: а) автомобилистов: SKID rhyming slang for 'kid'. 'Motorhead' jargon 'ребенок'; б) алкоголиков: вLUE LADY alcoholic's slang ‘метиловый спирт в качестве спиртного'; в) бродяг: NUTHOUSE originally tramps' slang from c.1905 = an asylum for the insane 'камера или отделение для психически неуравновешенных или склонных к суицидам заключенных’; г) магазинных воров: CURLY мо ...Also NZ shoplifter's jargon 'хорошо!', ‘идет!’; д) наркоманов и наркоторговцев: Н abbr. ... drug addicts' and peddlers' slang since the early 1920s. 'героин, наркотическое вещество класса «А», получаемое из молочка опиумного мака'; е) проституток: DOGS GET PLAYED, HOES GET PAID prostitutes' slang, referring to the services they provide (об услугах, предоставляемых проститутками); ж) уличных банд: CRIPSTER slang used by members of the Crips, a Homie gang 'заключенный, отбывающий пожизненное наказание' [9, p. 22, 49, 50, 59, 83, 127, 167].

Согласно профессионально-корпоративным маркёрам в словаре Д. Лузер второй вид мобильности проявляется в употреблении лексем (одновременном / асинхронном) не только представителями тюремного социума Новой Зеландии, но и членами того или иного профессионально-корпоративного жаргона в нескольких англоязычных лингвистических ареалах. В процессе межареальных переходов могут происходить изменения семантики ЛЕ. Приведем примеры тюремных жаргонизмов NZE, используемых также в следующих лексиконах в рамках макросистемы полинационального английского языка: а) армейском: кіт British army slang late 
19C-20C = belongings 'тюремное обмундирование, простыни, одеяла'; б) бродяг и нищих: ЈAск British tramps' and beggars' slang c.1854 = а policeman, с.1886 = а detective 'детектив', 'сыщик'; в) воровском: PEG US thieves' slang, from early 1920s. 'тщательно спланировать преступление'; г) заключенных: нUт Australian convicts' slang late 18C = convict living quarters 'камера'; д) золотоискателей: мULLocк from Australian and NZ mid-19C goldmining usage 'марихуана плохого качества'; е) наркоманов: MR BRownSTONE current US drug users' slang 'героин', 'героин, выращиваемый в Иране'; ж) наркоторговцев: DUтсну US drug traffickers' slang early 20C = narcotics 'сигарета с марихуаной'; з) уличном: воокіЕ current US street-slang = a police officer new to the force 'офицер полиции’, ‘сотрудник исправительного учреждения’ [Ibidem, p. 63, 91, 94, 101, 119, 120, 137-138, 155].

Локально-территориальная мобильность заключается в употреблении одних и тех же ЛЕ заключенными сразу нескольких исправительных учреждений Новой Зеландии, ср.: BUS SToP $n$. (in some prisons, e.g. Arohata, Manawatu, Mount Eden ...) 'небольшое помещение, где находится заключенный в ожидании допроса, конвоирования, сопровождения в суд и др.’ [Ibidem, p. 34].

Анализ социолингвистической вариативности тюремного жаргона NZE как специфической социально детерминированной формы существования NZE включает в себя описание его гендерных, локальнотерриториальных и социально-профессиональных характеристик. Рассмотрим их более подробно.

Половая дифференциация речевого поведения членов новозеландского тюремного социума на лексическом уровне представлена гендерно маркированными языковыми единицами, ср.: ғох вох women's prison argot 'караульное помещение', 'диспетчерская'; MASK UP (largely amongst male prison inmates) 'сознательно воздвигать эмоциональную преграду, которая служит барьером между истинными чувствами заключенного и внешними проявлениями его поведения, демонстрируемыми окружению’ [Ibidem, p. 74, 114].

На лексико-семантическом уровне гендерные особенности коммуникации представителей новозеландской тюремной субкультуры интенсивнее проявляются в речи заключенных мужского пола. Жаргонные номинации, используемые мужчинами, обозначают наиболее актуальные для них в семантическом плане понятия и практически не встречаются либо отсутствуют в лексиконе женщин-заключенных. Вследствие повышенной конфликтогенности и агрессивности мужского населения тюрьмы в словарном запасе последних нередко центрами синонимической аттракции (термин Т. М. Беляевой, В. А. Хомякова [1, с. 80-83]) становятся такие понятийные области, как «оружие» и «насилие»: воов соsн 'оружие округлой формы в виде затвердевших кусков мыла в носке', BLANKET Jов 'нападение, предполагающее использование одеяла или наволочки для того, чтобы ослепить жертву и остаться неизвестным', SANDwicн 'наброситься на человека, буквально зажав его между двумя участниками нападения’ [8, p. 42-43; 9, p. 24, 19, 158]. Вполне обоснованно, например, что вокруг доминанты кNIFE сконцентрированы многочисленные кодифицированные разговорные и просторечные синонимы: brush, dolly, flick, iron, point, shorty, steel, stick, tool, whiteboard marker [9, p. 2, 31, 59, 70, 93, 142, 167, 177, 178, 191, 203].

Исследуемый социолект отличается заметной локально-территориальной вариативностью по исправительным учреждениям Новой Зеландии, которая отражается в соответствующих пометах, cp.: LOWER CELL (Arohata Prison) 'камера с голыми стенами, оснащенная системой видеонаблюдения, в которой содержатся заключенные, склонные к самоубийству'; DOG KENNEL (Dunedin Prison) ‘прогулочный двор'; sCAREDY CATS (Invercargill Prison) 'тюремный блок, состоящий из четырех камер для опасных заключенных’; BATMAN AND RoвIN (Kaitoke Prison) 'сотрудники исправительного учреждения, которые берут у заключенных анализ мочи с целью обнаружения следов употребления наркотических веществ’; тшАск from Mangaroa (Hawke's Bay) Prison 'избиение'; снатеAU, тне (Mount Eden Prison) 'одиночная камера'; ОтаRA STREet (Ohura) 'ряд камер, где содержатся преимущественно наркозависимые’; coffin, тHE (Paremoremo Prison) 'специально оборудованная звуконепроницаемая камера для наиболее опасных или неуравновешенных заключенных’; LEVELS (esp. Waikeria) ‘дифференцированная форма наказания, применяемая в некоторых тюрьмах, в результате которой заключенный лишается привилегий и вынужден приобретать их снова хорошим поведением' [Ibidem, p. 14, 41, 45, 58, 107, 111, 159, 194, 179].

В ряде случаев локально-территориальная дифференциация социолекта может сочетаться с гендерной вариативностью. В исследуемом материале зафиксированы ЛЕ с одновременным наличием маркёров, указывающих на гендерную и локальную принадлежность носителей, ср.: ICE CREAM PARLOUR, THE (Mount Eden Men's Prison) 'курильная комната для персонала'; MAson Cunic (Mount Eden Women's Prison) ‘камера постоянного наблюдения за психически неуравновешенными и (или) склонными к самоубийству заключенными’ [Ibidem, p. 92, 114].

Социально-профессиональная вариативность тюремного жаргона NZE крайне слабо выражена и представлена единичными примерами, ср.: FROG IN THE MUD prison kitchen workers' slang 'кусочки киви в шоколадном пудинге быстрого приготовления’ [Ibidem, p. 74].

\section{Заключение}

Итак, в результате анализа мы приходим к следующим выводам. Социолексикографическое описание новозеландского пенитенциарного социолекта позволило раскрыть его социолингвистическую мобильность и вариативность. Тюремный жаргон NZE обнаруживает очевидную ареальную, локально-территориальную и профессионально-корпоративную мобильность. Ареальные черты реализуются при переходе в его состав лексем из $\mathrm{BrE}$, AusE, AmE и полинезийских языков (маори, самоа). Характерным признаком жаргона является рифмованный сленг. Профессионально-корпоративная мобильность проявляется в передвижении в социолект единиц из лексиконов преимущественно девиантных и маргинальных субкультур как внутри специального 
лексического субстандарта NZE, так и в рамках макросистемы полинационального английского языка. Локально-территориальная мобильность состоит в одновременном функционировании одних и тех же единиц в нескольких исправительных учреждениях Новой Зеландии. Социолингвистическая вариативность социолекта включает в себя гендерную, локально-территориальную и социально-профессиональную дифференциацию. Гендерная дифференциация более заметно проявляется в речевом репертуаре заключенных мужского пола, в том числе и на лексико-семантическом уровне, и представлена ЛЕ, вербализующими наиболее актуальные для них понятия. Тюремный жаргон новозеландского лингвистического ареала характеризуется локально-территориальной вариативностью по исправительным учреждениям Новой Зеландии. В социолекте зафиксированы единичные случаи проявления социально-профессиональной вариативности.

Перспективным представляется дальнейшее изучение социолингвистических свойств тюремного жаргона исследуемого лингвистического ареала.

\section{Источники | References}

1. Беляева Т. М., Хомяков В. А. Нестандартная лексика английского языка. М.: ЛИБРОКОМ, 2010. 138 с.

2. Коровушкин В. П. Английский лексический субстандарт versus русское лексическое просторечие (опыт контрастивно-социолектологического анализа). Череповец: ЧГУ, 2008. 167 с.

3. Коровушкин В. П. Основы контрастивной социолектологии: дисс. ... д. филол. н. Пятигорск, 2005. 640 с.

4. Коровушкин В. П. Теоретические основы контрастивной социолектологии. Череповец: ЧГУ, 2009. 246 с.

5. Рябичкина Г. В. Проблемы субстандартной лексикографии английского и русского языков: теоретический и прикладной аспекты: автореф. дисс. ... д. филол. н. Пятигорск, 2009. 45 с.

6. Трифанова С. С. Лексический субстандарт новозеландского варианта английского языка в синхронии и диахронии: автореф. дисс. ... к. филол. н. Санкт-Петербург, 2017. 18 с.

7. Трифанова С. С. О семантических особенностях номинации в новозеландском тюремном жаргоне (на примере лексико-семантической группы «заключенный») // Научный диалог. 2018. № 11. С. 63-75. DOI: 10.24224/ 2227-1295-2018-11-63-75.

8. Looser D. Boobslang: a lexicographical study of the argot of New Zealand prison inmates, in the period 1996-2000: in 2 vols. University of Canterbury, 2001. Vol. I. 156 p.

9. Looser D. Boobslang: a lexicographical study of the argot of New Zealand prison inmates, in the period 1996-2000: in 2 vols. University of Canterbury, 2001. Vol. II. 236 p.

\section{Информация об авторах | Author information}

RU Tрифанова Светлана Сергеевна ${ }^{1}$, к. филол. н.

${ }^{1}$ Вологодский институт права и экономики Федеральной службы исполнения наказаний

EN Trifanova Svetlana Sergeevna ${ }^{1}, \mathrm{PhD}$

${ }^{1}$ Vologda Institute of Law and Economics of the Federal Penitentiary Service of Russia

${ }^{1}$ tss7-lion@yandex.ru

\section{Информация о статье | About this article}

Дата поступления рукописи (received): 13.08.2021; опубликовано (published): 30.09.2021.

Ключевые слова (keywords): новозеландский национальный вариант английского языка; социальная дифференциация языка; тюремная субкультура; новозеландский тюремный жаргон; лексическая мобильность; New Zealand national variety of the English language; social differentiation of the language; prison subculture; New Zealand prison argot; lexical mobility. 